\title{
Role of Civil Society and Its Impact on Social Capital
}

\author{
Mr. Neelmani Jaysawal \\ Asst. Professor, Department of Social Work, Visva-Bharati, PO-Sriniketan, Distt.-Birbhum (West Bengal)
}

\begin{abstract}
Civil Society refers to the arena of unforced collective action based on shared interest, purposes and values. It consists of the groups and organizations both formal and informal, which act independently of the state and the market to promote diverse interests in society. As the machinery of welfare state is lagging far behind in responding to growing needs of individuals, the role of civil society has become imminent. It provides 'networks of civic engagement' within which reciprocity is learned and enforced, trust is generated and patterns of collective action are facilitated. It depends on people's active participation and is threatened when people and societies become excluded. Thus, Social Capital, the informal relations and trust which brings people together to take action, is crucial for the success of Civil Society.

Social Capital is the foundation for grassroots democracy because it brings cohesiveness among members of the society. People interact and share common values among them resulting in their upgrading socio-political consciousness.

This paper seeks to understand Civil Society and Social Capital with different perspectives established around the same. The paper will also attempt to explore the dynamic relationship between Civil Society and Social Capital through field realities.

Key Words: Civil Society, Social Capital, Co-ordinated action, Grassroots democracy, Collective action.
\end{abstract}

\section{Introduction:}

Every society takes decisions about its own affairs and determines the course of its general direction. In some societies these decisions are taken by an independent public authority that has a monopoly over institutionalized force. This particular form of public power is referred to as the State. By Civil society one refers to an arena of society constituted outside this public power, a region of society where people have come together and formed associations outside the purview of the state.

The central idea of civil society is as a mediating agency between individuals and the state: "civil society is associated with a set of institutions that mediate between the individual and the state...civil society is...seen as a modern phenomenon that emerges only when the principle of formal equality becomes the operative norm in society". Civil society and state are integral parts of a process of realizing formal democracy. The spread of Liberalization of the economy has furthered the conceptualization of civil society as a separate 'sector', different from the state and the market (Cohen and Arato 1992). In addition, the boundaries between the three spheres are not watertight but highly porous. Not only does the state define the playing field for civil society through its legal framework, it also creates enabling policies and environment for the market. Therefore there is no reason why civil society must always further the interest of the market and not question it.

The constitution of India guarantees the freedoms of speech and association to its people thereby providing a framework for civil society to operate in. From time to time, civil society not only challenges but extends the boundaries that are created by state. However, it does so within the limits prescribes by the state, suggesting that the state has the upper hand in controlling the initiatives of civil society. State does use violence to when these challenged by civil society. However, civil society cannot respond in the same way to such violence acts of state in order to survive. Hence, civil society initiatives have been largely carried out through peaceful demonstrations and dialogue that challenge the actions of the state but do not threaten its existence.

Civil society organizations impart citizens with skills and training that help in the art of the participation. This leads to the process of increased participation from the person which is very much essential for sustainable development and smooth functioning of democracy. The conceptualizations of civil society that vest it with the task of democratization are rooted in two traditions.

a. The Revolutionary image :

The revolutionary image of civil society makes it a site for contestation, where people counterpose themselves against state power and in the process either replace or reform it.

b. Tocquevillean interpretation

The civic associations perform the role of watchdogs in a democracy, which links civil society to the state (ibid). 
People's participation is a source of social capital for civil Society. Social capital is productive one which adds to increasing efficiency of society through a set of norms, institutions, networks, institutions like civil society an even the govt. organizations (Harriss, John; 2001)

Putnam defines social capital as those features of social organization such as trust, norms, networks that can improve the efficiency of society by facilitating co-ordinated actions.

Social capital is a kind of human resource of society in an integrated manner. It is formed through co-ordinated actions, cohesiveness among individuals, notion of help among members of different community. The way for creating social capital is a set of norms, co-ordinated behavior, formation of networks and communication through various organizations like NGOs, football clubs, adventure clubs, common meeting forums. In the way civil society, acts as an important player in creating social capital.

Social capital inheres, not just in civil society but in an enduring set of relationships that spans the public-private divide. According to some scholars, civil society in India consists of very fluid social groupings which are founded on primordial identities of caste, ethnicity, kinship, lineage and religion, though most political theories would write these groupings off as unworthy candidates for voluntary social associations whom they regard as the prime component of civil society.

It is assumed that the wellbeing of civil society depends upon its social capital and the way it works. A community mobilization process involves locally organized and planned, community intervention, where the individual stakeholders and other development workers such as health workers, NGO coalitions, Religious leaders, police, the media and local businesses collaborate on a range of complementary interventions. Therefore, it becomes essential to development practitioner in understanding Civil Society and Social Capital through the lens of Community Mobilization with different perspectives established around the same. The case studies of movements in Kerala and U.P. and Civil Society Organizations like Yuvshakti; Ghar Bachao Ghar Banao Andolan and All India Blue Star Employees' Federation will be helpful in exploring the dynamic relationship between Civil Society and Social Capital through field realities. In addition, it will reflect on the recent happenings and the positive as well as negative aspects of Social Capital in relation to Civil Society.

\section{Definition:}

Civil society has become one of the favorite buzzwords among the global chattering classes, touted by presidents and political scientists as the key to political, economic, and societal success. There are myriad definitions of civil society.

a. Carolyn M. Elliott says that Civil society is a space between the family and the state where people associate across ties of kinship, aside from the market, and independent of the state.

From above definition it arises that civil society includes both formal organization and informal networks of social life outside the family. It is both a collection of an organization and relatively protected space which they occupy.

b. The London School of Economics Centre for Civil Society states "Civil society refers to the arena of uncoerced collective action around shared interests, purposes and values. In theory, its institutional forms are distinct from those of the state, family and market, though in practice, the boundaries between state, civil society, family and market are often complex, blurred and negotiated. Civil society commonly embraces a diversity of spaces, actors and institutional forms, varying in their degree of formality, autonomy and power."

c. Social capital is an aggregate of the actual or potential resources which are linked to possession of a durable network of more or less institutionalized relationships of mutual acquaintance and recognition or in other words, to membership in a group which provides each of its members with the backing of the collectivity-owned capital, a credential which entitles them to credit, in the various senses of the word (Bourdieu: 1986).

d. Social capital is defined by its function. It is not a single entity, but a variety of different entities having two characteristics in common: they all consist of some aspect of social structures, and they facilitate certain actions of actors whether persons or corporate actors within the structure (Coleman 1988).

Social capital as defined by above thinkers confirms the view that it is not only ingredient in personal and familial relationship but a larger framework of social relationship. It envisages itself in a structure of friends and peer groups. But at the same time they create a kind of social stratification in the society because of which interest of a certain class is only fulfilled. They equate it in terms of a capital generating ideal framework of benefiting a certain class. An individual having formed social capital in his family disallows the kind of entrance of external members into this whole which leads to a dense social relationship. 


\subsection{Civil Society:}

\section{Evolution of civil society and social capital:}

The term civil society became a part of the general political discourse in sixteenth and seventeenth century Europe. Within civil society people had the right to choose their king and be governed by laws that pursued the minimum shared interests of the people. It initiated the process of questioning the centrality that was previously accorded to religious institutions and religious explanations. Later on theorists built on this concept and by seventeenth century, Civil society came to designate a distinct form of political society- one in which the rights of the individuals received primacy over everything else. Writing in late $17^{\text {th }}$ century, Locke differentiated civil society both from the state of nature as well as from political society. According to him civil society comes into existence when men possessing the natural right to life, liberty and estate come together, sign a contract and constitute a common public authority. Locke contrasts this civil society with the state of nature, where in the latter men have equal natural rights but there is no legal authority that can uphold these rights and punish its offenders. (Mahajan, Gurpreet;1999).

The idea of civil society that resurfaced during the late 18th century included political theorists, from Thomas Paine to Georg Hegel, who developed the notion of civil society as a domain parallel to but separate from the state -- a realm where citizens associate according to their own interests and wishes. This new thinking reflected on contemporary economic realities i.e. the rise of private property, market competition, and the bourgeoisie (Thomas Carothers).

Hegel and Marx used civil society as a concept to characterize the society emerging from urban industrial capitalism in the nineteenth century. The phrase which they both used in Germany, namely burgerliche Gesellschaft, meant Bourgeois society or civil society. Neither of them regarded burgerliche Gesellschaft as the highest form of historical development. Marx was infact critical of it. (Jayram, N.2005). By the mid19 ${ }^{\text {th }}$ century, civil society was largely seen as working with issues related to formal legal equality, the protection of property, and constitutionalism. During the $20^{\text {th }}$ century it culminated in a critique of welfarism and with the passage of time the second half of the twentieth century witnessed a loss of faith in the institution of state, which led to a rethinking on the earlier conception of Civil Society. This occurred in three diverse contexts:

- Similar to the Marxian understanding of the relationship between economic interest and political institutions

- in an attempt to revitalize participation of citizens in western democracies and

- in totalitarian regimes of socialist societies.

In the 1990s, civil society became a mantra or a buzzword for everyone right from presidents to political scientists. The global trend towards democracy opened up space for civil society in formerly dictatorial countries around the world. In the developing world, privatization and other market reforms offered civil society the chance to step in as governments retracted their reach. And the information revolution provided new tools for forging connections and empowering citizens (Thomas Carothers).

In its new avatar however, the concept of civil society appears to be in search of a reality. Interestingly even in the German language a neologism, zivil Gesellschaft, which means 'Civil Society' has now been introduced. This term came in because of the need felt by German scholars to distinguish between 'bourgeois society' and 'civil Society' as burgerliche Gesellschaft used by Engel and Marx is not only unsuitable but also misleading in the contemporary context.

Civil Society has carried a consistent focus if not an absolute conceptual unity, in its contemporary usage the concept is devoid of consensus. Z. A Pelczynski notes 'a few social and political concepts have travelled so far in life and changed their meaning so much'.(Jayaram,N. 2005)

\subsection{Social capital:}

The origin of social capital is one of the most controversial sociological idea in study of the social sciences. Although the term has been used for a long time, its origin is traced back to $20^{\text {th }}$ century. The first use of this concept can be interlinked with L.J Hanifan, who urged the importance of community involvement for good schools (Harriss, John; 2001, pg-17).

Later on, Meyer Fortes, an anthropologist spoke in terms of social capital in 1958. Then in mid-1970s an economist, Glen Loury proposed the idea again in work explaining the determinants of income differences between members of different racial groups of the U.S and his research influenced one of the two principal theoreticians of social capital, the American Sociologist James S. Coleman (Harriss,John;2001,Pg-17). On the other side, it influenced a French anthropologist Pierre Bourdieu who defined it in pure sociological terms.

Then an Italian political scientist Robert Putnam in his book 'Making Democracy Work' elaborated the whole concept of social capital. Putnam states that social capital is based on the foundation of thin trust rather than thick trust within societies. Thick trust makes a community rigid in terms of its composition. An individual may not transcend its boundary to co-opt with other communities in thick trust oriented communities. (Harriss, John; 2001) 


\subsection{Civil society :}

\section{Debates revolving around the concepts:}

\subsubsection{Hegel}

Hegel remarked that earlier societies did not possess civil societies. To him civil society was distinct from either the household or the state in a manner that the state is not only responsible for the creation of a civil society, but also for its sustenance. (Uberoi J.P.S in Jayram, N. 2005 pg.72). According to Hegel the creation of civil society is the achievement of the modern state that unifies the duality of civil life and political life (D.N Dhanagre ibid, pg. 45). Hegel enlarged the notion of civil society from the liberal emphasis on the market to include social practices distinct from economic life. Hegel perceived civil society as being egoist, selfish and fragmented. (Carolyn M. Elliot, 2003 pg.6). In addition, he argues that civil society does not arise out of natural ties of kinship and community. Instead it develops in the course of their actual attainment of selfish ends.

According to him civil or bourgeoisie is the realm of individuals who have left the unity of the family to enter into economic competition. It is the arena of particular needs, self interests, and divisiveness with potentials for self-distraction. The state comes into being because civil society is not in itself sufficient, and it does for civil society what it can not do for itself. Civil Society represents a step forward from feudal to bourgeois society (PKB Nayar in Jayaram, N. ,2005).

\subsubsection{Marx}

According to Marx, Civil society embraces the whole material intercourse of individuals within a definite stage of the development of productive forces. It embraces the whole commercial and industrial life of a given state and insofar transcends the state and the nation.

In the 'critique of Hegel's philosophy of rights' Marx emphasized the nexus between economic interests and political institutions. Focusing on the right to property sanctioned by civil society, he maintained that the latter lacked the ability to express universal interests common to society as a whole. Like the capitalist state it remained the voice of the ruling class. (M. Gurpreet, 99)

Marx tends to reduce the development of civil society to the structure of productive forces and social relations arising out of them. Since Marx thought statism, centralism and bureaucratism only organize, centralize and institutionalize social and political alienation which would by definition be authentically to civil society and therefore he considers civil society as belonging to the structural sphere, to "base" rather than to the superstructure (D.N Dhanagre in N.Jayaram, 2005).

\subsubsection{Gramsci}

To Gramsci, civil society belongs to the superstructural sphere. It comprises of not only material relationships, but all ideological cultural relations along with the whole of commercial and industrial life (D. N Dhanagre in Jayaram, N. 2005).

Unlike Marx Gramsci argues that Civil society is not simply a sphere of selfish and egoistic individual needs but of organizations representing broader community interests which have the potential of rational self regulation and freedom. According to Gramsci the concept of state includes elements of Civil society the state narrowly conceived as govt. is protected by hegemony of dominant class is fortified by the coercive state apparatus (PKB Nayar in N Jayaram, 2005).

Gramsci sets himself against the pure economic interpretation of Civil Society as laid down by Marx and his followers. Civil society is not to be found in the sphere of production or economic organization but in the state. The formula most commonly found in Gramsci is the state = political society plus Civil society. He further says that it is precisely in civil society that intellectuals operate especially, it is here that they perform their key function of supplying legitimacy and creating consensus on behalf of the ruling class (Kumar, Krishan, 93).

\subsection{Social capital:}

The idea of theorizing social capital was brought in 1980s and 1990s by three major thinkers of social sciences. Those thinkers are Pierre Bourdieu, Coleman and Putnam. Later on these proponents got split into two different schools of thought. One was Individual benefit group and second was Collective benefit group. Individual benefit group consisted of Bourdieu, Coleman and Mcclenaghan while Collective benefit group consisted of Putnam and Fukuyama.

\subsubsection{Bourdieu}

Bourdieu is called one of the pioneering proponents of the notion of social capital. For him, social capital is evidently socially and historically limited to the circumstances that create them. They are contextual and constructed. For Bourdieu, it is not enough to establish the existence of a network but to examine its cultural and ideological content and context. In terms of signifying the contextual aspect, Bourdieu states that social 
capital stems not only from subjective attributes but more profoundly from emergent and existing actions of many kinds(Harriss John; 2001 , pg- 22). He analyzes the social capital from the class angle. In his view, it is linked to these forms of capital that enter significantly into formation and reproduction of the class. It is evident through his statement that possession of durable social relationship is one condition of differential access to resources and an aspect of social differentiation.

\subsubsection{Coleman}

Coleman perceives social capital from neo- liberal economic point of view where social capital is a structure which facilitates certain actions of the individuals who are within structures. Like other forms of capital, social capital is productive making possible attainment of certain ends that would not be attainable in its absence. Coleman's conceptualization of social capital suggests the possibility of building social capital by encouraging investment in organization of this kind. He says that a social capital in a particular structure may be harmful for others.

Social capital is more activity oriented and subject oriented rather than universal for all activities. Coleman supports the closed boundary of social capital where norms of reciprocity are inherent within certain members. He gives the example of a child's performance being affected by kind of social capital in his family. In his view, a regular contact of a child with his elder person of family creates a kind of feeling of mutuality in the child which encourages him to form ties with batch mates even in his school. In contrast, an unhealthy relation between a child and his family members or shift of a child's home from one place to other, creates instability in mind of a child thus resulting into lack of interpersonal contact and coordination. Therefore social capital begins with individual and goes to social sphere.

\subsubsection{Putnam}

Robert Putnam relates social capital more with civic engagement. He says that norms of generalized reciprocity and networks of civic engagement give rise to social capital which in turn makes cooperation between people possible and reinforces reciprocity and civic engagement.

As per his view, a socio-economic development of the country depends upon nature of civic engagement in those socio-economic development processes. Civic engagement can be measured by the indicators like:

- Preference voting.

- Newspaper readership.

- Density of sports and cultural associations.

He says that stability of a democracy depends upon internal contact between people and their external influence upon wider polity. Even if people join a civil organization it will bring a sense of cooperation among them through which they could participate in their political affairs (Harris John; 2001, pg-25). Putnam states that social capital is possible in case of weak ties rather than strong ties. Networks that cut across social cleavages nourish wider cooperation. This is the reason Putnam focuses upon notion of bridging capital rather than bonding capital.

\section{Interrogating Civil Society and Social Capital:}

Civil Society depends on people's active participation and is threatened when people and societies become excluded. Thus, Social Capital, the informal relations and trust which brings people together to take action, is crucial for the success of Civil Society. With the help of following case studies an attempt has been made in interrogating civil society and social capital, which will reflect the interface between civil society, community and development practitioner as depicted in figure 1. In many countries, community-based organizations (CBOs) are being promoted at the village level to take responsibilities for a variety of rural development activities. Most government programs are emphasizing on adoption of participatory approaches envisaging participation of village communities through these institutions. Non-government organizations involved in rural development activities are also largely operating through CBOs. In some instances, CBOs have emerged without a direct assistance from government or non-government organizations and took responsibility of managing common property natural resources. 

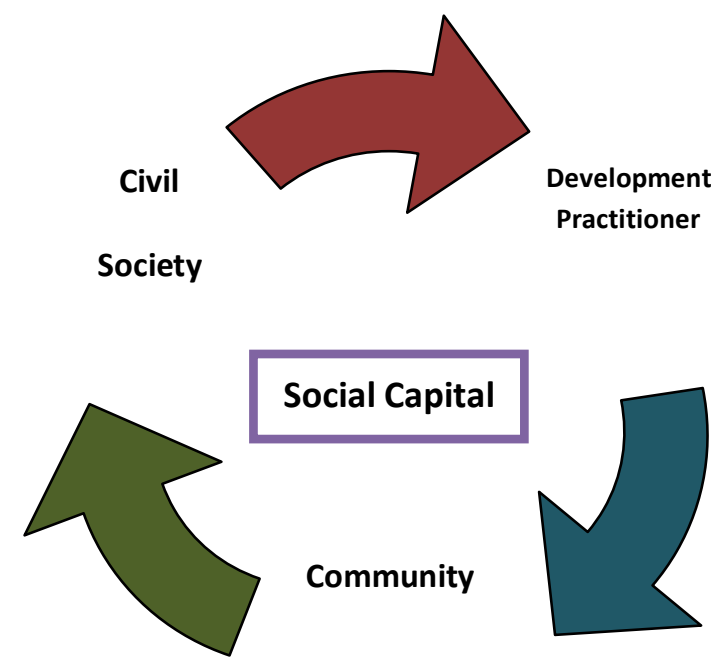

Figure 1: Interface between civil society, community and the role of development practitioner.

In the above figure the inter-relationship between individual, community, civil society and social capital has been tried to establish. Individual intervene in the community and deal with the community issues. In this process the formation of social capital starts taking place. Some agent of this social capital mixes with the individual and forms a shape of civil society. This formed civil society keep dealing with the community issues and continuous formation of civil society keeps taking place. This is the common feature of some types of civil society like CBOs, Movements etc. This can be further substantiated with the help of following case studies:-

\subsection{Case Study of Kerala :-}

If we see the reason behind fast social development of Kerala, we find that it is all ingredients in its historical traditions as well as various social movements. The rich social capital of Kerala is the evidence behind entire social development of the state. The movements in Kerala for social upgradation have not been restricted within one particular caste or class but it has invited the participation from all strata of the society. This can be substantiated with the help of following examples:

i. Movement going against the Hydropower Project at Pooyamkutty river.

The Project aspires to make a dam of 148 meters- high, which will result in the submersion of nearly 2000 hectares of forestland and 2 tribal settlements on the edge of this river. Then the KSSP (Kerala Shashtra Sahitya Parishad), which was a literary association, got involved in opposing this project. KSSP is an association, which was formed in 1962 for the sake of disseminating the knowledge related to Arts, Science to the poor people of Kerala. Its earlier aim was to enlighten people but due to presence of a massive problem in the state, it proceeded towards this movement. People belonging to Nambudris, Phuliyas, Izhavas castes participated in this movement being an active participant of KSSP. It established a fivemember committee in which they listed their arguments against the project. In this process, KSSP joined hands with various voluntary organizations in Kerala and began a prolonged and intense mass campaign against the project. Besides arranging meetings, lectures, seminars in mass media, KSSP lobbied the political leaders and the judiciary also.

ii. Movement against Palmolein:-

Apart from it, another movement has started in the state since 2000, which is related to the livelihood of the coconut farmers. The availability of imported Palmolein at a cheaper price has affected the coconutgrowing farmers. This edible oil is substituting the coconut oil that is a sign of danger for the interest of the farmers. So the farmers have started their agitation against the sale of this oil. This movement, which had 100000 members earlier in 2001, has the support of the farmers from across other states of India.

iii. Movement against mechanization of the fishing industry:- 
In addition to it, another movement had also been a symbol of harmonious relationship among various groups in Kerala. The movement is Fishermen's movement which started by late 1970s against the mechanization of fishing industry. The use of modern fishing instruments increased the profits of the elite fishing community but segregated the traditional fishing community. Now only the mechanized fishermen could export their fish while the traditional fishermen stuck to the domestic market only. Then the people raised the concern, which was not only supported by the fishing community but even catholic church.

People formed an association called All Kerala Independent Fishermen' Federation (AKSMTF) which comprised of persons from all strata of the society like Hindus, Muslims, Christians and several dalits. Thus, this association put the pressure on the contemporary Kerala government to address their problems. In 1984, a spree of picketing started in several parts of the state to stop vehicle movement on highways as well as trains. The women were in the forefront of this movement. In this way, the state government had to set-up a committee to investigate the problem and provide recommendations. Now at the recommendation of Murari committee, the central government has taken several steps in 1997 to cancel all these licenses given to these deep-sea trawlers and protect the interest of the traditional fishermen.

Therefore, if we see the kind of development going on in Kerala, we shall find that it is driven by its long inter-cultural cohesiveness among several villages along with thin line of social networks among the community. The people in their caste or religious entities are not restricted to a certain ideology. Whenever it is needed, they collaborate at cross-community level also. The groups are ready to compromise with their own ideology over the issue of larger social importance. Village communities, gram-sabhas regularly hold the meetings, air complaints and plan projects. The people of one village take help from other villagers also even if it is directly affecting the people of only a particular village. Although there are various groups formed based on their caste and their religion but group loyalty has not prohibited them from joining other groups in the area to protest. The presence of strong bonds within the group has also helped the mobilization process. These groups have flexible coordination among their members, which allow them to join other protest movements even outside the agenda of their group. De Nardo calls it 'a network of networks' where there are two types of bonding; one is within the members of a certain group and second is inter-group bonding. For enhanced participation, an extended group network is needed, not restricted participation within the group. Another major cause behind the success of the protest movements in Kerala is mobilization through small organizations and a kind of mutual cohesiveness among them. The people in Kerala organized themselves in small groups over various micro issues and coordinated when the case of larger mobilization came into forefront. They have brought a kind of associational life where women of these villages have formed Mahila-mandals which run Aanganwadis.

From the above explanation it becomes clear that the strong bond, which exists at the group level, does not restrict the people of Kerala from being a part of the larger network. Rather, such a strong bond helps to recruit support for the movement at the micro level, while bridging ties with other groups helps in spreading the movements at the meso level. So it can be reflected as a classic example of strong social capital prevalent in the area.

\subsection{Yuvshakti:-}

In response to the socio-political calamity of 2002 in Gujarat, Yuvshakti was initiated as a project of Janvikas. It works in the worst affected Talukas (Halol, Kalol, Ghoghamba) in Panchmahal District, Gujarat. It is a movement that works for a long term systematic intervention to lead conflict transformation processes through youth empowerment. Due to the sudden stoppage of industries in the towns the youth lost their livelihood. Political parties make use of these large sections of unemployed youth for their purpose that aggravated the riots.

Yuvshakti identified that youth has their own issues and should work towards it as one community i.e. 'Youth Community'. The programmes of Yuvshakti:-

- Jan Adhikar

- Basera

- Sathi Information

- Sakshi Media

- Meghadhanush

- PYNM (Panchmahal Yuva Nagrik Manch)

- Unnati

Through its various said programmes it mobilized youth around the issue of conflict transformation. It build its rapport and organized youth by using various strategies like allowing the usage of Sathi information centre for imparting information and guidance on accessing government schemes and programmes and meetings with the 
community youths, panchayat members, etc. In this way social capital was further strengthened by imparting legal awareness among people and providing them livelihood options. In addition, youth groups were formed in different talukas and provided training on dealing with community issues and conflict transformation. Thus, making youth socially, politically and economically empowered. Some of the benchmark that development practitioner able to achieve with the help of social capital and civil society was to be able to link the government schemes and programmes with the community; legal awareness among people about their rights; capacity building of youth conflict transformation.

Here, with the help of case study an attempt has been made to highlight the strong propositions that civil society works effectively to form social capital. However, on the other hand there is some scope of improvement. The youth groups feel helpless in dealing with the community issues like PDS (Public Distribution System) as the babus and bureaucrats have strong social capital among them who prevent in dealing with corruption. Therefore it becomes essential to sustain the motivation and interest of its social capital and equipping them with the knowledge and skills on contemporary issue and technology.

\subsection{All India Blue Star Employees' Federation :-}

All India Blue Star Employees' Federation is a federation of the permanent workers working in Blue Star firm which came into existence in the year 1971. In order to earn profit the employer exploits the labour in numerous ways. Trade union has come at a particular situation in the society recognizing the need for labour to organize and assert their rights. One individual person can't do anything s/he needs collective bargaining because it gives power to negotiate and assert the rights. This is where the role of trade union comes in to make labour conscious about their issues and exploitation of their rights. All the four companies of the Blue Star in different regions amalgamated and formed one umbrella known as Blues Star Ltd. It was a landmark as the workers were brought together by the company itself and civil society. The workers saw it as good opportunities to organize themselves, which shows the rise of social capital among them around the issues affecting them like no defined working hours and low wages.

In year 1975, one federation comprising of four unions under Blue Star Ltd. was formed, which came to be known as All India Blue Star Employees' Federation. The Union enabled workers to engage in the process of bargaining with firms and assert their rights. In addition, it brings the sense of unity and security among workers that further helped in strengthening the newly emerged social capital. This social capital acts as a force to negotiate at the management level. On the said issues and issues like no safety wears, no social security measures, no health benefits.

"Whenever we are in large numbers we can form union but three or four workers can't form union", shared by an activist in the federation. In addition, there is an emerging giant issue of the exploitation of the workers by the hands of the firm through forced VRS (Voluntary Retirement Scheme). The civil society became able to address the contemporary labour issues and due to this social capital (workers) enabled to negotiate at various levels with the management and assert their rights. However, the main problem that the trade unions face is that some of them are divided on Political lines as expressed by a unionist in the federation. Due to this there is a wide gap between the members of the union. Due to the coming of the political parties, the issues of workers are getting sidelined.

\section{Critical assessment of Civil Society and Social Capital:}

$>\quad$ Keane says that inequality and domination has been built in concepts of civil society and they have been there from the start. Keane says that historically it rests on the foundation of excluded women who are expected to live under conditions of household despotism. Today the problem of exclusion is raised not only by gender groups but also by ethnicity, sexuality (Flyvbjerg Bent).

$>\quad$ John Harriss criticizes the whole notion of social capital and civil society. He says that the idea of social capital was not an established part of the development lexicon until 1997. Now it is the subject of an attractive and well produced entity of the world bank. It is based on the Washington consensus which propagates the viewpoint that market must decide the development of the people. On the other side its opponents say that market economy of East Asia has shown that a state run market can lead to growth, not a free market economy.

$>$ It is also criticized that social capital is concerned with the neo-liberal agenda of reducing the role of the state to make possible large cuts in public expenditure. It is also said that social capital is formed by the industrial units in the sense that an informal relationship between workers can resolve the conflicts between manager and workers quietly. They will ensure a healthy growth of the industries.

$>$ Since most of the civil society literature came from western society, class cleavages are often taken as the model for contestation with civil society, hence this is not easily transferred to the non-western countries where capitalism is not ascendant nor is class the basis of identity.(Elliott M Carolyn, 2003.pg 9). For eg. The caste associations in India are substantially similar to the norms of intentional associations featured in 
civil society analysis. Caste associations challenge the common sociological distinction between inherited and chosen identities. (ibid)

$>\quad$ Mark Robinson says that it is frequently difficult to distinguish between civil and political organizations because the same or related organizations are active in both sectors. His account of Hindu politics in India shows how militant nationalists are seeking to create an ideological hegemony through such civil society institutions as the media, research institutes, religious bodies, youth organizations while also pursuing power through a cadre based political party (Elliott M. Carolyn, 2003, pg. 10).

$>\quad$ In many settings local governments display more of the qualities of voluntary association than of the state. They often function as lobbies for local interests confronting a hierarchical bureaucracy for eliciting voluntary participation by citizens in collective projects. Trade unions and employers associations in western states often work so closely with government that distinguishing between government and civil society becomes difficult (ibid, pg10-11).

$>\quad$ The statement of Putnam that social capital can be measured only by civic engagement and resource base of individual members in the community, doesn't fit into case of India. Policy makers have understandable difficulty in confronting messiness of the social reality and they necessarily resort to frameworks that seem to cut through complexity. It is seen that social capital understood in terms of the social resources is not necessarily a good predictor of poverty reduction strategies or pro- poor urban governance.

$>\quad$ JRF (Junior Research Fellowship) researchers argue that social capital is very affected by the way our society interacts with neighbourhood. Level of social cohesiveness determines the stock of social capital. They say that a social capital is not isolated from the power- relations. It is ingrained within the power structure of the society. They said that social capital matters but its promotion must be framed within a process of democratization that should be an integral objective of community development. A healthy social capital can't be expected where material inequality is there. In such a situation a resourced person will form their own small groups leaving issues of general masses untackled.

\section{Conclusion:}

Civil society and social capital, are very much interrelated to each other. People started getting organized and raising voices on their rights and issues affecting them, which highlights the importance of strong social capital. In addition, the participation of people is the recognized strength by the civil society. Disintegration of social capital may affect the civil society in adverse ways and vice-versa. The model that explained the practioner as a separate entity in the realm of Civil society and community shows the challenges and responses in today's context. The explanation of the case studies was helpful to explore the dynamic relationship between Civil Society and Social Capital through field realities. It gave an idea about how to solve the problem coming in the way of formation of social capital and ensure participation of the masses at large scale. Civil society, social capital is integrated entities for each other. In this way, the existence of social capital is an instrument to form a strong bond of community resulting into formation of civil society.

\section{References}

[1]. Bhattacharya, Dwaipayan, 2004: Interrogating Social Capital; The Indian experience: New Delhi, Sage publications.

[2]. Carolyn M. Elliott, 2003: Civil Society and Democracy, New Delhi, OUP.

[3]. G. Ajay,Vijay G; Civil Society, State and Social Movements, Economic and Political Weekly, Vol. xxxv No. 12, (March 18, 2000), Pg. 1035-36

[4]. Harris, John, 2001: Depoliticizing Development, New Delhi, Leftword.

[5]. Mahajan, Gurpreet; Civil Society and Its Avatars: What Happened to freedom and democracy, conomic and political weekly, Vol. XXXIV No. 20, (15th May, 1999), Pg.1188-96.

[6]. N. Jayram, 2005: On Civil Society, New Delhi, Sage Publications.

[7]. Tandon, Rajesh and Ranjita Mohanty, 2003: Does civil society matter, New Delhi, Sage publications.

\section{Websites:}

- http://www.umanitoba.ca/institutes/disaster_research/brazil/report3.html

- http://www.vialibri.net/item_pg/1730572.htm

- http://www.jstor.org/stable/1149558

- http://www.answers.com/topic/civil-society

- http://www.jstor.org/stable/591808

- http://www.crlra.utas.edu.au/files/discussion/2002/D2-2002.pdf)

- http://www.istr.org/conferences/capetown/volume/jain.pdf) 